\title{
An Empirical Study of Perceived Factors Affecting Customer Satisfaction to Re-Purchase Intention in Online Stores in China
}

\author{
Shahzad Ahmad Khan 1*, Yan Liang1, Sumaira Shahzad² \\ ${ }^{1}$ School of Economics and Management, China University of Geosciences Wuhan, China \\ ${ }^{2}$ School of Geographic Information System, China University of Geosciences Wuhan, China

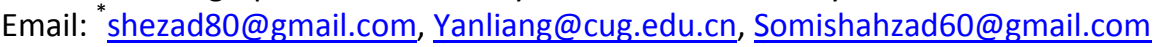

Received 23 March 2015; accepted 21 April 2015; published 8 May 2015

Copyright (C) 2015 by authors and Scientific Research Publishing Inc.

This work is licensed under the Creative Commons Attribution International License (CC BY). http://creativecommons.org/licenses/by/4.0/

c) (i) Open Access

\begin{abstract}
Online stores (e-stores) are growing in China. Consumers perceive some factors affecting their satisfaction to re-purchase intention in e-stores. This study investigates the perceived factors affecting customer satisfaction to re-purchase intention in e-stores. The satisfaction toward the online stores channel environment depends on the customer's perception and also online consumer experiences (OCEs) of the active online shopping stores. From a questionnaire survey, 302 usable data are obtained and hypotheses are tested using multiple regression analysis. The analysis suggests that seven constructs-price, convenience, product information, return policy, financial risk, product risk and delivery risk-are significant with customer satisfaction to re-purchase in estores. This study emphasizes that the importance of customer satisfaction provides more benefits and less risk to re-purchase in e-stores. The finding of this study will help e-store's managers/ owners to understand customer's perceptions in online shopping stores and their satisfaction.
\end{abstract}

\section{Keywords}

Online Shopping, Online Stores (e-Stores), Perceived Risks, Perceived Benefits, Customer Satisfaction, Re-Purchase Intention, China

\section{Introduction}

Online shopping has become very popular in China. Due to fast-moving life and shortage of time, now consum-

\footnotetext{
${ }^{*}$ Corresponding author.
}

How to cite this paper: Khan, S.A., Liang, Y. and Shahzad, S. (2015) An Empirical Study of Perceived Factors Affecting Customer Satisfaction to Re-Purchase Intention in Online Stores in China. Journal of Service Science and Management, 8, 291-305. http://dx.doi.org/10.4236/issm.2015.83032 
ers are searching for their desired products in online shopping stores. As many shoppers are shopping online, the importance of online stores is growing with the passage of time. Consumers can get benefit through comparing prices at different online stores at the same time which they can't do in a physical store. Online shopping environments are therefore playing an increasing role in the overall relationship between online stores and their customers [1]. Today's online consumers have more control and bargaining power than consumers of physical stores because the Internet offers more interacts between customers and products/ service providers as well as greater availability of information about products and services. Reibstein [2] described that it was very important that consumers were content with the products and services provided by the particular e-store as satisfied customers were likely to be loyal and made repetitive purchases which would increase profitability of that particular e-store.

Over the past few decades, Internet has developed into a comprehensive global marketplace for the exchange of goods and services in China. Internet users in China have been an explosive growth in the last decades. By the end of 2014, China has had a total of 332 million online shoppers, a growth of 29.62 million compared with that at the end of 2013, with a semi-annual growth rate of 9.8\%. Compared with December 2013, the percentage of online shoppers in China rose from $48.9 \%$ to $52.5 \%$ [3]. At the end of 2015, those consumers will be spending \$1000 million per year online and the same amount of online shopper spending annually in U.S. 170 million. People in China shop online mainly for three reasons: greater product selection, compare prices and convenient (Acquity Group Survey).

Online stores have been growing in a highly competitive market, and frequently high competition is increasing over the customer's demands, needs and switching, so there is a need to be informative about the factors that influence the customers. A fundamental understanding of factors impacting online customer satisfaction is vitally important for e-stores [4]. A number of studies have been examined the influence of consumers' perceived risk and perceived benefits separately and with different factor. In their study, Liu and Brock [5] described in detail about Chinese consumers' perceived benefits, perceived risk and trust influence on group buying. Our study is to survey customer satisfaction to re-purchase intention with perceived affecting factors which included benefits and risk in the environment of B2C (Business to Consumer) online shopping stores.

This study contributes to the literature by investigating empirically the relationship among customer satisfaction, perceived benefits, perceived risk, and re-purchases intention. This research emphasizes the importance of more benefits and less risk to influence customers re-purchases intention in e-stores..

The purpose of the present study is to:

1. Help the e-stores to understand customer's perceptions in online shopping.

2. Investigate the relationship between customer satisfaction and perceived factors.

3. Finally to put forward some recommendations to the e-store's managers/owners in order to improve the customer satisfaction to re-purchase intention.

\section{Literature Review and Hypothesis Development}

\subsection{Customer Satisfaction}

Satisfaction is important to the individual customer as it falls down an optimistic outcome from the specific resources and the fulfillment of unmet wants and needs [6]. Customer satisfaction is defined by Oliver the consumer's fulfillment response. It is a judgment that the product or service provides a pleasurable level of consumption-related fulfillment, including levels of under- or over fulfillment [7].

The rapid growth of online shopping in China emphasizes the importance of focusing on the issue of customer satisfaction as a key factor for discussion when designing any online stores. A growing body of literature proposes models for customer satisfaction [8] [9] and many of these studies have tried to identify factors that lead to customer satisfaction.

According to Rodger's Innovation Diffusion Theory, Rogers presented a comparative advantage as one of the factors that influence shopper's decision and satisfaction of desire and cheaper price, convenience and return policy can all be discussed as comparative advantages [10]. Many researchers have been investigated during the last few years to find out customer satisfaction and perception of the difficulties that preventing the development of online shopping [11]. Many of them identified different variables by which customers get satisfaction and make a re- purchase intention in e-stores. Devaraj et al. [12] measured customer satisfaction in the e-commerce perspective and reinforced empirically that satisfaction was a basic factor of consumer channel preference. Cus- 
tomer satisfaction reflects the amount of customer's positive feeling for e-stores in online shopping. It is important for e-stores retailers to understand the customer vision of their services. Online consumers need additional satisfaction when buying from e-stores otherwise the customers switch to other e-stores [13].

Childers et al. [14] related the customer satisfaction and attitude toward online shopping with the Technology Acceptance Model (TAM) where they refer the ease-of-use of technology as the "processing of practice the new media while engaging in shopping behavior". For Technology Acceptance Model, Davis [15] describes that user's adoption of a given information technology can be explained by the consumer's intention to use the system, which in turn is determined by the consumer's beliefs about the system. The TAM has been used and modified by numerous studies and has been proved to be a reliable predictor of a person's acceptance of information technology [16]-[18].

Recently, researchers have found that satisfaction positively impacts on loyalty and re-purchase intentions toward online shopping [19]. It is evidence from the literature that satisfied customer show a greater intention to use company's products and have a lower intention to find from other e-stores [20]. Therefore, e-stores prefer customer satisfaction as crucial to attain sustainable growth and competitive advantage in online shopping [21]. Subramanian et al. [22] described Chinese customer satisfaction as purchasing experience reliability and responsiveness of quality service of e-stores drives them to re-purchase intention.. We expect that once users achieve certain levels of satisfaction with prior use of e-stores, the perception of satisfaction will influence their re-purchase intentions. It is necessary for e-store's managers to know customer's wants and needs, understand their hitches, fear and threats perceived by them while shopping in online stores

\subsection{Re-Purchase Intention}

The individual's judgments about buying again a designated product or service from the same e-store take into account his/her current situation and likely circumstances. Re-purchase intention refers to the likelihood of using a service provider again in the future [23]. Daugherty et al. [24] stated that re-purchase intention was a measure of response behavior and consumer reaction to certain experiences. Kim and Kim [25] described that online stores had the potential to influence customer's re-purchase intention if they convinced that online shopping was interactive by providing rich information about the product performance and chatting communication and offering decent store layouts in terms of quality graphics and images. Customer's intention to repurchase online goods and services has been studied as a manifested form of loyalty towards this alternative way of buying [19]. Kim et al. [20] pointed out that satisfaction was the strongest predictor of re-purchase intention of customers in online stores.

The TAM theory developed by Davis explained user's acceptance of technology in the workplace. TAM adopts a causal chain of beliefs, attitudes, intention, and plain behavior that social psychologists Fishbein and Ajzen [26] have put forward, and that has become known as the Theory of Reasoned Action (TRA). Based on certain beliefs, a person forms an attitude about a certain object, on the basis of which he/she forms an intention to behave with respect to that object. The intention to behave is the prime determinant of the actual behavior.

Therefore, it is concluded that a satisfied customer is more likely to make another online purchase and intention to buy, to recommend online buying to his friends, colleagues or relatives and finally, to patronize online buying over traditional buying. Many researchers have begun to postulate satisfaction as the main predictor of customer's intention to repurchase online [15] [27]-[32].

$\mathbf{H}_{\mathbf{1}}=$ Customer satisfaction has a direct positive effect on re-purchase intention in online stores.

\subsection{Online Stores in China}

Online stores was initiated by Pizza Hut in 1994 with an online ordering service on their web page in USA. Amazon was another one which started selling real time tangible products through websites, and later eBay also started an online auction [33]. The first Chinese B2C e-store Alibaba Group (http://www.alibaba.com/) was founded in 1999 by 18 people led by Jack Ma, a former English teacher from Hangzhou, China, he has wished to make the Internet accessible, and to facilitate beneficial for everyone, followed by the establishment of the $1^{\text {st }}$ C2C e-store Eachnet. It was at the time that Internet was a new technology for most Chinese people. In 2003, Taobao was launched by Alibaba Group and eBay also acquired Eachnet and then started working and became the biggest competitor of Taobao.com. Chinese online shopping market was developed rapidly in 2005 (Liberation Daily, 29th August 2009). In 2007, many merger and acquisition happened in the e-commerce industry and 
several big online shopping stores: Taobao, eBay, PaiPai, and Amazon.com and they started competitive online business. Tmall.com was also launched by Taobao stores in 2008 to supplement its consumer-to-consumer (C2C) market coverage and became an independent platform in 2011. Tmall.com has established an open business-toconsumer (B2C) platform itself as the destination for good quality, brand-name goods catering to increasingly sophisticated Chinese consumers.

China's e-market has grown with an average rate of 70\% from 2009-2012 vs. $13 \%$ in America, and its total size is expected to reach RMB 3.3 trillion (\$539.07 billion) by 2015 (Bain and Company report, 15 January 2014). The B2C market scale hit RMB 227.86 billion ( $\$ 37.3$ billion), accounting for $35.2 \%$ of the total online shopping market in China. And in China, more online shopping platforms are rapidly flourishing. However, the growth of online shopper will depend in part on potential obstacles and risks, including the security of personal information, dissatisfaction with products, and goods delivery that do not meet customer's expectations and so on [34]. E-stores can facilitate convenient and approachable online purchasing process, serve their customers better and improve customer satisfaction to increase re-purchase retention [35].

E-stores have numerous advantages compared to physical stores; e-stores are easy access and time saving and no more waiting in lines and traveling is needed. These stores provide consumers with rich information and free about products and services. Online stores accept orders 24 hours a day and 7 days a week while consumers who wish to shop at traditional stores have to be available to visit the store during normal business hours. Online shopping reduces this concern because consumers can simply access e-stores from their computer whenever they have free time and wherever they are. It is also noted that shopping easier is one of the main motivations of consumer's online purchasing [36].

\subsection{Perceived Benefits}

Perceived benefits are beliefs about the positive outcomes related to a behavior in response to a real or perceived threat. Eastin [37] described perceived convenience, financial benefits, risk and easy interface were all important factors besides perceived benefits and perceived ease of use and customer satisfaction as the core motivation of consumers' online shopping decision.

Prior research on satisfaction has proposed perceived benefits as critical predictors of satisfaction. Different modules of perceived benefits have been verified as positively impacting on satisfaction [38] [39]. So, perceived benefits increase re-purchase intention among consumers in online shopping stores, as price, convenience, and return policy are benefits perceived by customers [35].

\subsubsection{Price}

Price is an important motivation to attract consumers to make a shopping on e-stores, a below market price for a product in e-stores have reinforced and abolished effect on the consequence of leaving the online shop. For Chinese consumers, value shopping entails looking for discounts, sales, or hunting for price promotions [40]. Chinese consumers are value seekers and they search hard for the super deals to make sure they get good worth for their money. So, they spend a lot of time seeking quality products and compare prices. Many online consumers expect e-stores offer price promotions or have lower prices than offline stores [41].

Marketing literature described price as an important factor for customer satisfaction because customers always refer to price when assessing product and service value [23] [42]-[44]. Biswas and Blair [45] conclude that the price discount could affect customers' price belief, and ultimately affect their shopping satisfaction.

$\mathbf{H}_{2}=$ A price benefit is positively related to customer satisfaction on re-purchase intention in e-stores.

\subsubsection{Convenience}

Another benefit expected to influence the acceptance of online environments is perception of convenience as it manifests the opportunity to shop at home 24 hours/7 days a week [46]. Yu et al. [47] also indicated the positive relationships among perceived usefulness, convenience and behavioral intention. This obvious benefit of online shopping which cannot be overlooked is convenience. This convenience in interactive shopping increases search efficiency through the ability to shop at home, by reducing such frustrations as fighting traffic and looking for a parking space, and avoiding long checkout lines, while also offering single "stop" shopping that avoids traveling to or from a different store. It was found that this construct directly affected satisfaction. Seiders et al. [48] revealed that access convenience interacted with satisfaction in terms of influencing consumers' future intentions. 
$\mathbf{H}_{3}=$ A convenience benefit is positively related to customer satisfaction on re-purchase intention in e-stores.

\subsubsection{Product Information}

An important factor affecting the effectiveness of satisfaction using sensible thought is product information. Product information sharing is defined as the usefulness of the available information about an attribute of a product in helping a decision maker to evaluate the product. Appropriate information is the key to consumer's consumption in e-stores, that is why a vital question for companies is how information about products and services is presented to consumers on the Internet [49]. The quality information has a strong impact on those customers that perceives a great risk, probably because information sharing helps consumers overcome these fears and form a more favorable opinion of using e-stores. Hence the online shopping experience greatly depends on the website information to compensate for the lack of physical contact; online quality information becomes crucial. Information sharing is measured by the cumulative importance of the attribute information [50]. Product information plays a critical role in purchasing decision in e-stores. Information and knowledge about the product are positively related to customer satisfaction [51].

$\mathbf{H}_{4}=$ A product information is positively related to customer satisfaction on re-purchase intention in e-stores.

\subsubsection{Return Policy}

Consumers are concern about terms of return policies before shopping a product. Return policy is lenient in case the product does not perform as described and need to be exchanged or a refund. In return policy rebate is implemented to compensate the customers which is defined as a return of part of the original payment for some service or merchandised; partial refund. When shopping online, customers rated the functional attributes like price, ease of movement and ease of return as important [52]. The high-quality e-stores can offset the increased costs of honoring return policies with increased revenues from customers. Low-quality e-stores, though, will not use easy return policies because they know that their low quality means that many orders will be returned and the costs of returning merchandise will be higher than any increased revenues from customers attracted by easy policies [53]. Online stores offer return provisions for their customers for a variety of reasons. These stores desire to remain competitive in the face of rivals' liberal return policies, or they believe that customer satisfaction is a valuable asset for business [54]. When customers perceive a lower level of uncertainty and are more familiar with the products and the e-store, they will return less and order more products which in turn will lead to higher profits for the company [55].

$\mathbf{H}_{5}=$ A return policy benefit is positively related to customer satisfaction on re-purchase intention in e-stores.

\subsection{Perceived Risk}

The risk is perceived by consumers when intending a specific consumption decision. Perceived risk is an expecting of the uncertainty about the possible outcomes of a behavior and the possible unpleasantness of these outcomes [56] and consumer feels fear about loss or gain in that specific consumption. Bauer [57] was the forerunner of the theory of perceived risk that consumers often perceived a risk at the time of their purchases. Perceived less risk is important in influencing customer satisfaction and decision by e-stores acceptance [58]. Perceived risk is an important factor that affects customer's buying decision in online shopping, through the perceived theories the consumer can know clearly which step owns higher risk in the whole shopping process [59]. Perceived risk is considered as a multi-faceted building up of physical risk, psychological risk, social risk, financial risk, product performance risk and risk of loss of time/delivery [60]-[63]. On the other hand, Forsythe and Shi [56] have explored the various types of risk perceived by Internet shoppers and mentioned three types of risk—product risk, financial risk and delivery/time risk are related to online shoppers to make a decision and customer satisfaction to re-purchase intention.

\subsubsection{Product Performance Risk}

Product risk is defined as the loss incurred when a brand or product does not perform as described by Horton [64]. A higher perceived product quality may increase the perceived value and, consequently, a customer satisfaction and re-purchase intention [65]. Consumers shopping online do not know physically about the product, they see the product in e-stores as they search for and buy products. In e-stores, consumers may develop low trust and perceive elevated highly risk because of the lack of face-to-face communication and physically sense 
(looking, touching, tasting and smelling). Perceived product quality uncertainty is very important in inducing consumer's perceived risk of e-stores [66]. Although this difficulty can be reduced by using certain software tools, 3D images, videos, a money transfer safety, refund and return and other associated platforms such as online recommendation agent [67]. It is identified that buying a product from a familiar brand might reduce the product risk of buying online as customers know the familiar e-stores and always get positive outcomes [68].

$\mathbf{H}_{6}=$ A bad performance of product risk negatively related to customer satisfaction on re-purchase intention in e-stores.

\subsubsection{Financial Risk}

Jacoby and Kaplan [69] described that perceived financial risk was the possibility of monetary loss arising from online shopping; these can stolen detail information of credit card, bank account and direct hack of money transaction. Many studies show that perceived overall financial risk tends to decrease when e-stores use safety cues [70], therefore, it is proposed that perceived financial risk is influenced by the customer's image of the estores. When online stores use safety cues such as ensuring high protection of online transactions, refund, they may build trust toward the e-stores and thereby enhance the e-stores image. Many credible corporate initiators, for example, Alibaba (http://www.alibaba.com/) have begun using a secure online payment system to lower financial risk, namely Alipay, similar to PayPal, which allows the trusted entity/bank to hold the buyer's payments and forward them to the seller after all buyers have received the products. When consumer feels secure about financial loss, then he/she buys the product without any hassle.

$\mathbf{H}_{7}=$ A perceived financial risk is negatively related to customer satisfaction on re-purchase intention in estores.

\subsubsection{Delivery Risk}

The delivery risk which is ever perceived by the customer is on-time delivery (OTD) and delivery without damage. Delayed delivery has a negative impact on satisfaction. Online purchases are unable to use or consume the product by customers immediately and they must wait for product delivery [71], but delivery delay annoyed the customer and next time customer will not consider buying from the e-store as they do not deliver product on time. Chang and Wang [72] also stated that delay of delivery caused negative results and customer dissatisfaction.

$\mathbf{H}_{\mathbf{8}}=$ Delivery risk is negatively related to customer satisfaction on re-purchase intention in e-stores.

\section{Research Model}

A research model (Figure 1) is designed to verify the online stores' satisfaction of Chinese customer to re-purchase intention and the factor influencing on their satisfaction. From the previous study literature [73] and present customer's affecting factors, we design a research model to examine the effect of perceived benefits and perceived risk on customer satisfaction to re-purchase intention in e-stores.

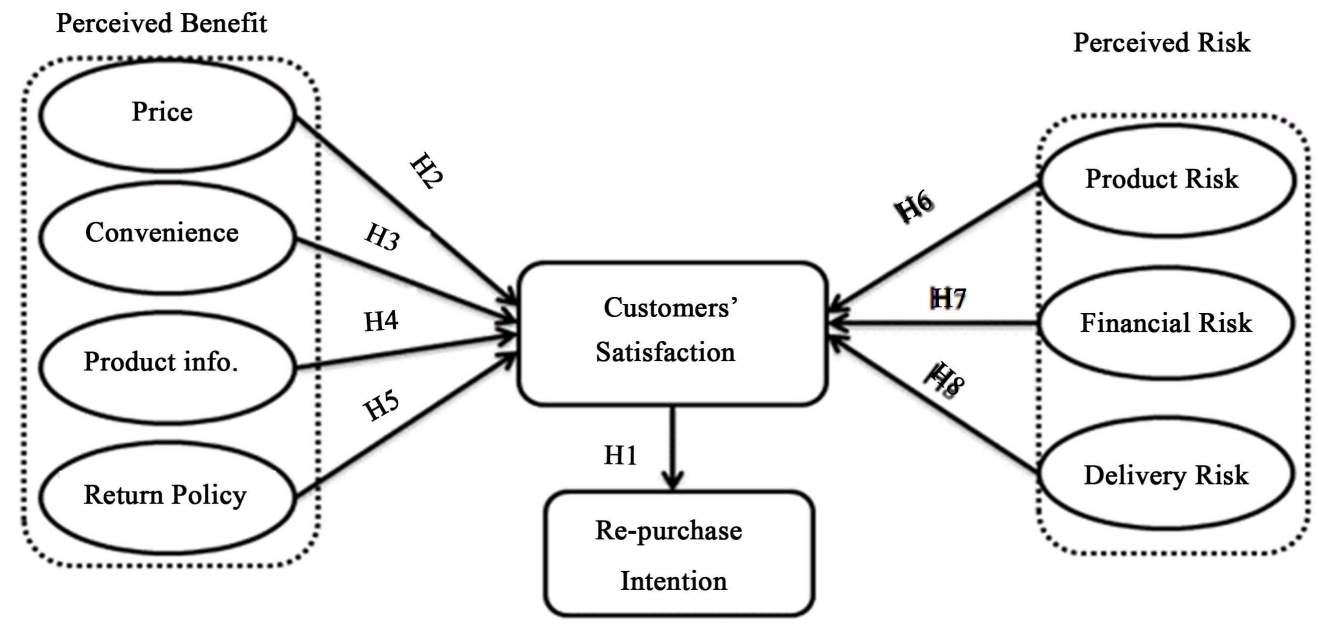

Figure 1. Conceptual model for customers' satisfaction to re-purchase intention in online stores. 


\section{Research Methodology}

Chinese consumers are excited to shop online and search for low price, better quality product and also have to face many factors affecting their satisfaction to re-purchase intention. From the previous study literature, we try to explore those factors which currently influence customer satisfaction to re-purchase intention in e-stores. This goal will be achieved by examining the effect of perceived benefits (Price, Convenience, Product information, Return policy) and perceived risk (Product risk, Financial risk, Delivery risk) factors with dependent variables customer satisfaction on re-purchase intention in e-stores as the hypotheses of the study.

These items were measured at a 5-point Likert type scale with "5" being "strongly agree" and " 1 " being "strongly disagree”. We also follow Anderson and Srinivasa [74] and Oliver's [75] multi-item scale to measure the customer satisfaction in an e-store context. We also included demographic data of respondent and overall 23 types of questionnaire were asked to measure these items to the persons who are shopping online.

\subsection{Sampling}

Most of the users are students and office workers between the ages of 18 to 45 years old. The students are mostly trying new things and with a low price and office workers search better quality with comparable prices. Half of Internet users in China are between the age of 20 and 40 [76]. For these reasons, the target samples for the current research were Chinese between 18 and 45 years old. Sample data was collected from China in these big cities (Beijing, Shanghai, Guangzhou and Wuhan). We filled the questionnaires from those consumers who were already shopping online and had some experience of perception. Such an approach may be appropriate because some researchers believe that customer satisfaction is limited to individual transactions [77].

\subsection{Data Collection}

Based on the model constructs, a questionnaire of 26 questions, as shown in appendix A, was designed to collect data for testing the model. Data was collected through direct approach, mails and emails questionnaire sent to different university's students and working office people in 4 big cities of China (Beijing, Shanghai, Guangzhou and Wuhan), 135 questionnaires were sent through emails, QQ messenger and friends to friends through post mail requesting to collect the data from their respective universities and 190 questionnaires were filled directly by approaching the peoples receiving online purchased parcels from delivery service offices, working offices and universities. As a result, 124 questionnaires were responded through post mails, emails, QQ messenger and 190 directly collected; finally 302 questionnaires were usable for analyzing. This survey was done from October 2014 to December 2014.

\section{Data Analysis and Results}

\subsection{Demographic Characteristics}

The composition of the respondents indicates that there are more female (55.63\%) than male (44.37\%) participation including teachers (14.90\%), students (55.30\%), own business (7.95\%) and working office staff (21.85\%); 80.12\% were aged between 20 - 40 years old. Most of the respondents were highly educated 55.30\%. Further, $65.56 \%$ of respondents were shopping on e-stores since 2 - 5 years ago, all of participation have bought something in the year recently and 37.09\% of them go shopping online twice a month, while 32.12\% go shopping online once a month (Table 1). Further, the chi-square test revealed that no significant differences were found in the demographics (i.e., Gender, Age, Education, Shopping experience and times of re-purchased). The non-significant differences were treated as sufficient assurance that the data obtained was likely to be a fair representation of the population of interest.

\subsection{Validity and Reliability}

We evaluated the construct discriminant validity and reliability with SPSS 19.0 and confirmatory factor analysis with LISREL 8.7. Confirmatory analysis provides satisfactory support for the 9-dimension model as shown in Table 2.

To confirm reliability and internal consistency of the measures, Cronbach’s coefficient alpha on the standar- 
Table 1. Demographic characteristics sample $(n=302)$.

\begin{tabular}{|c|c|c|c|}
\hline Item & Category & Frequency & $\%$ \\
\hline \multirow{2}{*}{ Gender } & Male & 134 & 44.37 \\
\hline & Female & 168 & 55.63 \\
\hline \multirow{4}{*}{ Job } & Teacher & 45 & 14.90 \\
\hline & Student & 167 & 55.30 \\
\hline & Own Business & 24 & 7.95 \\
\hline & Office Worker & 66 & 21.85 \\
\hline \multirow{4}{*}{ Age } & Less than 19 Years Old & 18 & 5.96 \\
\hline & 20 - 30 Years Old & 151 & 50.00 \\
\hline & 31 - 40 Years Old & 97 & 32.12 \\
\hline & More than 41 Years Old & 36 & 11.92 \\
\hline \multirow{5}{*}{ Education } & College degree & 73 & 24.17 \\
\hline & Under Graduate & 62 & 20.53 \\
\hline & Graduate & 134 & 44.37 \\
\hline & Doctorate & 28 & 9.27 \\
\hline & Post-Doctorate & 5 & 1.66 \\
\hline \multirow{5}{*}{$\begin{array}{l}\text { How Many Years } \\
\text { Shopping Online }\end{array}$} & Less than 1 Year & 48 & 15.89 \\
\hline & 2 - 3 Years & 67 & 22.19 \\
\hline & 3 - 4 Years & 82 & 27.15 \\
\hline & 4 - 5 Years & 49 & 16.23 \\
\hline & More than 5 Years & 56 & 15.64 \\
\hline \multirow{4}{*}{$\begin{array}{l}\text { How Often Purchased } \\
\text { Online Stores }\end{array}$} & Once a Month & 97 & 32.12 \\
\hline & Twice a Month & 112 & 37.09 \\
\hline & Twice a Year & 45 & 14.90 \\
\hline & Once a Year & 48 & 15.89 \\
\hline
\end{tabular}

Table 2. Means, standard deviations, composite reliabilities and correlations.

\begin{tabular}{|c|c|c|c|c|c|c|c|c|c|c|c|c|c|}
\hline Constructs & CR & Ave & Mean & STD & PC & $\mathrm{CN}$ & PI & $\mathrm{RP}$ & PPR & FR & DR & CS & RPI \\
\hline Price & 0.85 & 0.61 & 4.67 & 1.17 & 1.00 & & & & & & & & \\
\hline Convenience & 0.78 & 0.52 & 4.09 & 1.12 & 0.43 & 1.00 & & & & & & & \\
\hline Product Information & 0.88 & 0.57 & 4.56 & 0.98 & 0.53 & 0.42 & 1.00 & & & & & & \\
\hline Return Policy & 0.91 & 0.63 & 4.41 & 1.04 & 0.49 & 0.51 & 0.50 & 1.00 & & & & & \\
\hline Product Perform Risk & 0.79 & 0.66 & 4.38 & 1.13 & 0.36 & 0.37 & 0.43 & 0.39 & 1.00 & & & & \\
\hline Financial Risk & 0.81 & 0.62 & 4.46 & 1.09 & 0.40 & 0.31 & 0.44 & 0.48 & 0.56 & 1.00 & & & \\
\hline Delivery Risk & 0.76 & 0.79 & 4.34 & 1.18 & 0.32 & 0.27 & 0.35 & 0.31 & 0.30 & 0.38 & 1.00 & & \\
\hline Customer Satisfaction & 0.83 & 0.68 & 4.59 & 1.02 & 0.48 & 0.41 & 0.39 & 0.45 & 0.38 & 0.44 & 0.40 & 1.00 & \\
\hline Re-Purchase Intention & 0.81 & 0.77 & 4.39 & 1.16 & 0.35 & 0.30 & 0.40 & 0.39 & 0.42 & 0.29 & 0.36 & 0.38 & 1.00 \\
\hline
\end{tabular}

Notes: CR = Composite Reliabilities; Ave = Average Variances Extracted; STD = Standard Deviations. Correlations are below the diagonal and all values are significant at $\mathrm{p}<0.01, \mathrm{p}<0.05$. 
dized items was calculated for each constructs, ranged from 0.76 to 0.91 . After assessing the overall model fit, composite reliability was estimated by construct reliability. All construct reliabilities were located in $0.76-0.91$, as shown in Table 2 . They exceeded the criterion of 0.700 . Therefore, composite reliability of the measurement model was good.

In addition, to measure the discriminant validity among constructs, the average variance extracted (AVE) was calculated and compared to the squared correlation values among the constructs. As noted in Table 2, all AVE values were above the 0.50 threshold suggested by Fornell and Larcker [78] as necessary to infer internal convergent validity. The results of confirmatory factor analysis in this study show GFI (goodness-of-fit-index) of model-fit measure is 0.95, NFI (normalized fit index) is 0.94, and CFI (comparative fit index) is 0.95. Confirmatory factor analysis (CFA) loading was used to purify the scales with the objective of improving the congeneric measurement properties of the scales [9]. According to Bagozzi and Yi [79] if the model-fit measure is close to or above 0.9 standard levels,then the convergent validity of the items is within the acceptable range.

\subsection{Multivariate Regression Analysis}

Multiple regression analyses were conducted to examine the hypotheses $\mathrm{H}_{2}, \mathrm{H}_{3}, \mathrm{H}_{4}, \mathrm{H}_{5}, \mathrm{H}_{6}, \mathrm{H}_{7}$ and $\mathrm{H}_{8}$. The purpose of multiple regression analysis is to find the linear combination of the independent variables that correlate maximally with the dependent variable. A step-wise regression identifies the independent variable that best predicts the dependent variable. In step-wise regression the independent variable having the highest correlation with the dependent variable is selected first (a-g). The independent variable best correlated with the dependent is included in the equation. This is followed by entering the second variable of the remaining independent variables with the highest partial correlation with the dependent, controlling for the first independent, and so on. This process is repeated at each stage, partial link for previously-entered independents, until the addition of the remaining independent variables do not increase $R^{2}$ by a significant amount [80]. In order to further analyze the affecting factors of customer satisfaction in e-stores, here is the equation of standard regression of dependent variable, customer satisfaction:

$$
\mathrm{Y}=\beta 0+\beta 1 \mathrm{X} 1+\beta 2 \mathrm{X} 2+\beta 3 \mathrm{X} 3+\beta 4 \mathrm{X} 4+\beta 5 \mathrm{X} 5+\beta 6 \mathrm{X} 6+\beta 7 \mathrm{X} 7+\xi
$$

where $\mathrm{Y}=$ Customer satisfaction; $\beta 0=$ Constant; $\beta 1=$ the coefficient of the first; $\mathrm{X} 1=$ Price; $\mathrm{X} 2=$ Convenience; X3 = Product Information; X4 = Return Policy; X5 = Product Performance Risk; X6 = Financial Risk; X7 = Delivery Risk; and $\xi=$ the error or the difference between the predicted and the observed value of $Y$.

Table 3 shows the regression analysis, the theoretical hypothesis, model, and seven independent variable regression coefficients were $0.555,0544,0.512,0.406,0.326,0.301,264$. The value of these regression coefficient

Table 3. Regression coefficients.

\begin{tabular}{ccc}
\hline Independent Variables & Beta & Sig. \\
\hline Product Performance Risk & 0.555 & $0.000^{\mathrm{a}}$ \\
Financial Risk & 0.544 & $0.000^{\mathrm{b}}$ \\
Price & 0.512 & $0.000^{\mathrm{c}}$ \\
Return Policy & 0.406 & $0.000^{\mathrm{d}}$ \\
Product Information & 0.326 & $0.000^{\mathrm{e}}$ \\
Delivery Risk & 0.301 & $0.000^{\mathrm{f}}$ \\
Convenience & 0.264 & $0.000^{\mathrm{g}}$ \\
F Value & 37.214 & 0.602 \\
R Square & 0.491 & \\
Adjusted R Square & &
\end{tabular}

Note: ${ }^{\mathrm{a}-\mathrm{g}}$ In step-wise regression the independent variable having the highest correlation with the dependent variable is selected first. 
reflects the effects of variables on the overall satisfaction degree, the greater the absolute value is, the greater the impact is. By examining the change law of digital variables, a specific value indicated to identify variables affected by other variables Analysis results are shown in Table 3: regression model of $\mathrm{F}$ statistic are greater than the value of 37.214 and p value is 0.000 , namely model reached the significant level. The analysis results show whole fitting degree is higher.

Results concluded from the analysis: the first is the product performance risk (beta $=0.555, \mathrm{p}<0.01$ ), the financial risk (beta $=0.544, \mathrm{p}<0.01$ ), the price (beta $=0.512, \mathrm{p}<0.01$ ), the return policy (beta $=0.406, \mathrm{p}<0.01$ ), the product information (beta $=0.326, \mathrm{p}<0.01$ ), the delivery risk (beta $=0.301, \mathrm{p}<0.01$ ) and convenience (beta $=0.264, \mathrm{p}<0.01)$ has significant positive influence on customer satisfaction. Results supported the theoretical assumptions $\mathrm{H}_{2}, \mathrm{H}_{3}, \mathrm{H}_{4}, \mathrm{H}_{5}, \mathrm{H}_{6}, \mathrm{H}_{7}$ and $\mathrm{H}_{8}$.

The results of regression analysis of customer satisfaction and re-purchase intention are shown in Table 4 below.

The regression models of $\mathrm{F}$ values were greater than 7.123 , and $\mathrm{p}$ value is 0.000 , namely model reaches the significant level, and the whole fitting degree is higher. Customer satisfaction and re-purchase intention of the regression coefficient are: $0.712,0.502$, showing the customer satisfaction to re-purchase intention has a significantly positive influence, which supports the theoretical hypothesis $\mathrm{H}_{1}$ : customer satisfaction has a direct positive effect on re-purchase intention in online stores.

\section{Discussion and Conclusions}

This study provided support for these hypotheses regarding the linkage among the construct of research framework. China e-market is flourishing quickly and consumers are in search of more benefits and less risky in online shopping. Therefore, a customer care is necessary for the satisfaction to re-purchase on e-stores. Our survey found that $80.14 \%$ persons were shopping between 20 and 40 years old as described by CNNIC report. The results from the samples supported the proposed measures of factors affecting customer satisfaction to re-purchase intention in online shopping stores. Discriminant validity, reliability, and confirmatory factor analysis (CFA) supported the construct validity of 4-dimension perceived benefits and 3-di- mension perceived risk. Perceived benefits were determined to be a positive predictor of customer satisfaction while perceived risk related negatively to customer satisfaction. Finally, a practical assessment of these scales revealed that customer satisfaction could be fulfilled through greater benefits and less risk for re-purchase intention in online stores.

The result of these hypotheses Table 3 through regression analysis perceived benefits $\mathrm{H}_{2}, \mathrm{H}_{3}, \mathrm{H}_{4}$ and $\mathrm{H}_{5}$ were significantly supported and it indicated that price, convenience, product information and return policy are important for customer satisfaction to re-purchase in online stores (Table 5). This finding is consistent with the study of Thomas and Harry [81], revealing that the respondents with experience in online stores are more likely to be influenced by price for satisfaction to re-purchase intention.

Similarly the results of tested the hypotheses Table 3 through regression analysis perceived risk $\mathrm{H}_{6}, \mathrm{H}_{7}$ and $\mathrm{H}_{8}$ are significantly supported and it indicates that product risk, financial risk and delivery risk are negatively effective to customer satisfaction (Table 5) and e-store's managers/owners should reduce these risks to create re-

Table 4. Regression analysis of customer satisfaction and re-purchase intention

\begin{tabular}{|c|c|c|c|c|c|c|}
\hline ANO & & & & & & \\
\hline & Model & Sum of Square & df & Mean Square & $\mathrm{F}$ & Sig. \\
\hline \multirow[t]{3}{*}{1} & Regression & 17.021 & 5 & 4.223 & 7.123 & 0.000 \\
\hline & Residual & 39.23 & 53 & 0.712 & & \\
\hline & Total & 56.251 & 58 & & & \\
\hline \multirow[t]{3}{*}{2} & Regression & 34.432 & 4 & 7.451 & 18.601 & 0.000 \\
\hline & Residual & 25.032 & 51 & 0.502 & & \\
\hline & Total & 59.464 & 55 & & & \\
\hline
\end{tabular}


Table 5. Summary of hypothesis tests.

\begin{tabular}{lc}
\hline \multicolumn{1}{c}{ Hypotheses } & Results \\
\hline $\mathbf{H}_{\mathbf{1}}$ : Customer satisfaction has a direct positive effect on re-purchase intention in e-stores. & Supported \\
$\mathbf{H}_{2}$ : A price benefit is positively related to customer satisfaction on re-purchase intention in e-stores & Supported \\
$\mathbf{H}_{3}$ : A convenience benefit is positively related to customer satisfaction on re-purchase intention in e-stores. & Supported \\
$\mathbf{H}_{4}$ : A product information is positively related to customer satisfaction on re-purchase intention in e-stores. & Supported \\
$\mathbf{H}_{5}$ : A return policy benefit is positively related to customer satisfaction on re-purchase intention in e-stores. & Supported \\
$\mathbf{H}_{6}$ : A bad performance of product risk negatively related to customer satisfaction on re-purchase intention in e-stores. & Supported \\
$\mathbf{H}_{7}$ : A perceived financial risk negatively related to customer satisfaction on re-purchase intention in e-stores. & Supported \\
$\mathbf{H}_{8}$ : Delivery risk negatively related to customer satisfaction on re-purchase intention in e-stores. & Supported \\
\hline
\end{tabular}

purchase intention. The tested results ANOVA in Table 4 show that the hypothesis $\mathrm{H}_{1}$ customer satisfaction directly affects re-purchases intention in online stores. Researchers have proved in their study that satisfaction is the main predictor of customer's intention to re-purchase online [27]-[32]. Satisfaction is the main motivation that drives people to adopt online shopping and re-purchase in e-stores. According to Roger's Innovation Diffusion, Rogers presented relative advantage as one of the factors that influence shopper's decision and satisfaction of desire. Early theories of customer satisfaction, Oliver [7] proposed the Expectancy-Disconfirmation Paradigm (EDP) as the most promising theoretical framework for the assessment of customer satisfaction. So it is concluded that satisfied customers intend to re-purchase in e-stores and become loyal to that e-store.

\section{Managerial Implications}

According to the findings of this study, customers consider the product price, convenience and product information and return policy as important benefits for customer satisfaction to re-purchase intention in online stores. Similarly customers feel fear of risks while shopping in e-stores, so there is a need to reduce risk for customer satisfaction to re-purchase intention in online stores.

Keep in mind: online store's managers/owners should offer abundant choices to consumers, as well as offering competitive product prices. As we surveyed that Chinese consumers were more sensitive about price. The e-store's managers/owners should influence consumers through social media with ads and promotions for discounts available.

Convenience is important, especially for new consumers; some e-stores make very lengthy process to buy a product online. As a result, most consumers leave shopping in a half way due to transfer money and non-acceptance of common money-paying cards.

Detailed and complete product information should be provided. Before buying process consumers want to know about products information that is shared by e-stores. Retailer should share more information about products by using short video about product performance and 3D pictures.

Managers should pay more attention to implement return policies to facilitate the customer as if the product performance, damage and other reasons could be returned back.

Customers shopping online do not know physically about the product and performance. They only see the product features and images in e-stores. In e-stores, consumers may develop low trust and perceive elevated highly risk because of the lack of physical sense (looking, touching, tasting and smelling). Therefore, to enhance customer's degree of satisfaction, e-store's retailers should contribute clear, understandable information and quality of the product should be the same as described at company's website.

E-store's managers/owners should introduce a mechanism (e.g. Alipay by Alibaba Group in China) that would improve safety to motivate people to re-purchase online stores. Consumers should not be worried about losing their money and other financial information.

Prompt delivery plays an important role in Chinese customer satisfaction. To satisfy consumers in today's competitive e-commerce, online store retailers must keep a close eye on timely delivery and customer service. Delayed delivery and ignorance of customer's concerns will cause customer dissatisfaction. 
Customer satisfaction should be preference in order to provide more benefits and less risky shopping environment.

\section{Limitations of the Study and Future Research}

In this study, we identified seven factors, there may be other factors affecting in online shopping stores but in our study we didn't examine all those factors affecting online shopping stores. Our research was limited in 4 cities of China due to lack of finance and approach. We collected the data from 4 big cities of China as a sample. The study was limited to university students and office working peoples those were already shopping online stores. According to our survey, university students and office workers are appropriate because online consumers are generally younger and more highly educated people according to the survey of CNNIC report. Because of time and cost constraints, we only examined factors affecting customer satisfaction to re-purchase intention in online stores in China, while other countries consumers may have different characteristics and satisfaction levels and re-purchase intention.

Future research can develop more detailed models that can capture and explain more factors that may affect the customer satisfaction on e-stores like web service quality, product guarantee and privacy risk.

\section{References}

[1] Koo, D.-M., Kim, J.-J. and Lee, S.-W. (2008) Personal Values as Underlying Motives of Shopping Online. Asia Pacific Journal of Marketing and Logistics, 20, 156-173. http://dx.doi.org/10.1108/13555850810864533

[2] Reibstein, D. J. (2001) What Attracts Customers to Online Stores, and what Keeps Them Coming Back? Journal of the academy of Marketing Science, 30, 465-473. http://dx.doi.org/10.1177/009207002236918

[3] CNNIC (2014) The 33rd Statistical Report on Internet Development in China. China Internet Network Information Center. http://www.internetstatistik.se/rapporter/33rd-statistical-report-on-internet-development-in-china/

[4] McKinney, V., Kanghyun, Y. and Zahedi, F. (2002) The Measurement of Web Consumer Satisfaction: An Expectation and Disconfirmation Approach. Information Systems Research, 13, 296-315. http://dx.doi.org/10.1287/isre.13.3.296.76

[5] Liu, M.T., Brock, J.L., Shi, G.C., Chu, R.W. and Tseng, T.-H. (2013) Perceived Benefits, Perceived Risk, and Trust: Influences on Consumers' Group Buying Behavior. Asia Pacific Journal of Marketing and Logistics, 25, 225-248. http://dx.doi.org/10.1108/13555851311314031

[6] Bearden, W.O. and Teel, J.E. (1983) Selected Determinants of Consumer Satisfaction and Complaint Reports. Journal of Marketing Research, 20, 21-28. http://dx.doi.org/10.2307/3151408

[7] Oliver, R.L. (1980) A Cognitive Model of the Antecedents and Consequences of Satisfaction Decisions. Journal of Marketing Research, 17, 460-469. http://dx.doi.org/10.2307/3150499

[8] Woodruff, R.B., Cadotte, E.R. and Jenkins, R.L. (1983) Modeling Consumer Satisfaction Processes Using ExperienceBased Norms. Journal of Marketing Research, 20, 296-304. http://dx.doi.org/10.2307/3151833

[9] Anderson, J.C. and Gerbing, D.W. (1988) Structure Equation Modeling in Practice: A Review and Recommended Two-Step Approach. Psychological Bulletin, 103, 411-423. http://dx.doi.org/10.1037/0033-2909.103.3.411

[10] Rogers, E.M. (2003) Diffusion of Innovations. 5th Edition, Free Press, New York.

[11] Jarvenpaa, S.L. and Todd, P.A. (1997) Consumer Reactions to Electronic Shopping on the World Wide Web. International Journal of Electronic Commerce, 1, 59-88.

[12] Devaraj, S., Fan, M. and Kohli, R. (2002) Antecedents of B2C Channel Satisfaction and Preference: Validating ECommerce Metrics. Information Systems Research, 13, 316-333. http://dx.doi.org/10.1287/isre.13.3.316.77

[13] Kim, S. and Stoel, L. (2004) Apparel Retailers: Website Quality Dimensions and Satisfaction. Journal of Retailing and Customer Services, 11, 87-109. http://dx.doi.org/10.1016/S0969-6989(03)00010-9

[14] Childers, L., Carr, C.L., Peck, J. and Carson, S. (2001) Hedonic and Motivations for Online Retail Shopping Behavior. Journal of Retailing, 77, 511-535. http://dx.doi.org/10.1016/S0022-4359(01)00056-2

[15] Davis, F.D. (1989) Perceived Usefulness, Perceived Ease of Use and User Acceptance of Information Technology. MIS Quarterly, 13, 319-339. http://dx.doi.org/10.2307/249008

[16] King, W. and He, J. (2006) A Meta-Analysis of the Technology Acceptance Model. Information and Management, 43, 740-755. http://dx.doi.org/10.1016/j.im.2006.05.003

[17] Gefen, D., Karahanna, E. and Straub, D. (2003) Trust and TAM in Online Shopping. MIS Quarterly, 27, 52-85.

[18] Wang, Y.S. (2003) The Adoption of Electronic Tax Filing Systems: An Empirical Study. Information Quarterly, 20, 
333-352. http://dx.doi.org/10.1016/j.giq.2003.08.005

[19] Chiu, C.M., Lin, H.Y., Sun, S.Y. and Hsu, M.Y. (2009) Understanding Customers’ Loyalty Intention toward Online Shopping: An Integration of Technology Acceptance Model and Fairness Theory. Behavior and Information Technology, 28, 347-360. http://dx.doi.org/10.1080/01449290801892492

[20] Kim, J., Jin, B. and Swinney, J.L. (2009) The Role of E-Tail Quality, E-Satisfaction and E-Trust in Online Loyalty Development Process. Journal of Retailing and Consumer Services, 16, 239-247. http://dx.doi.org/10.1016/j.jretconser.2008.11.019

[21] Deng, Z.H., Lu, Y.B., Wei, K.K. and Zhang, J.L. (2010) Understanding Customer Satisfaction and Loyalty. International Journal of Information Management, 30, 299-300. http://dx.doi.org/10.1016/j.ijinfomgt.2009.10.001

[22] Subramanian, N., Gunasekaran, A., Yu, J., Cheng, J. and Ning, K. (2014) Customer Satisfaction and Competitiveness in the Chinese E-Retailing: Structural Equation Modeling (SEM) Approach to Identify the Role of Quality Factors. Expert Systems with Applications, 41, 69-80. http://dx.doi.org/10.1016/j.eswa.2013.07.012

[23] Fornell, C. (1992) A National Customer Satisfaction Barometer: The Swedish Experience. Journal of Marketing, 56, 6-21. http://dx.doi.org/10.2307/1252129

[24] Daugherty, T., Li, H. and Biocca, F. (2008) Consumer Learning and the Effects of Virtual Experience Relative to Indirect and Direct Product Experience. Psychology and Marketing, 25, 568-586. http://dx.doi.org/10.1002/mar.20225

[25] Kim, E.-Y. and Kim, Y.-K. (2004) Predicting Online Purchase Intentions for Clothing Products. European Journal of Marketing, 38, 883-897. http://dx.doi.org/10.1108/03090560410539302

[26] Fishbein, M. and Ajzen, I. (1975) Belief, Attitude, Intention and Behavior: An Introduction to Theory and Research. E-Commerce: The Role of Familiarity and Trust. Omega, 28, 725-737.

[27] Lee, H., Choi, S.Y. and Kang, Y.S. (2008) Formation of E-Satisfaction and Repurchase Intention: Moderating Roles of Computer Self-Efficacy and Computer Anxiety. Expert Systems with Applications, 36, 7848-7859. http://dx.doi.org/10.1016/j.eswa.2008.11.005 http://business.kaist.ac.kr/re_center/fulltext/2008/2008-091.pdf

[28] Tsai, H.-T, Huang, H.-C. (2007) Determinants of E-Repurchase Intentions: An Integrative Model of Quadruple Retention Drivers. Information and Management, 44, 231-239. http://dx.doi.org/10.1016/j.im.2006.11.006

[29] Chen, Y.Y., Huang, H.-L, Hsu, Y.-C. and Tseng, H.-C. (2010) Confirmation of Expectations and Satisfaction with the Internet Shopping: The Role of Internet Self-Efficacy. Computer and Information Science, 3, 14-22. http://dx.doi.org/10.5539/cis.v3n3p14

[30] Chen, C.-W.D. and Cheng, C.-Y.J. (2009) Understanding Consumer Intention in Online Shopping: A Respecification and Validation of the DeLone and McLean Model. Behaviour and Information Technology, 28, 335-345. http://dx.doi.org/10.1080/01449290701850111

[31] Lee, M.-C. (2010) Exploring Consumers Initial Intention and Continuance Intention to Use Online Shopping: An Extension of the Expectation-Confirmation Model. BAI 2010 Proceeding Papers. http://bai-conference.org/files/BAI2010\%20Proceeding/Papers/2.Marketing/2147.pdf

[32] Liao, C., Liu, C.-C., Liu, Y.-P., To, P.-L. and Lin, H.-N. (2011) Applying the Expectancy Disconfirmation and Regret Theory to Online Consumer Behavior. Cyberpsychology, Behavior, and Social Networking, 14, 241-246.

[33] (2010) Amazon's 15th Anniversary: A Brief History of Online Shopping.

[34] Liao, S.H., Chu, P.H., Chen, Y.J. and Chang, C.C. (2012) Mining Customer Knowledge for Exploring Online Group Buying Behavior. Expert Systems with Applications, 39, 3708-1644. http://dx.doi.org/10.1016/j.eswa.2011.09.066

[35] Kwon, W.S. and Lennon, S.J. (2009) What Induces Online Loyalty? Online versus Offline Brand Images. Journal of Business Research, 62, 557-564. http://dx.doi.org/10.1016/j.jbusres.2008.06.015

[36] Bridges, E. and Florsheim, R. (2008) Hedonic and Utilitarian Shopping Goals: The Online Experience. Journal of Business Research, 61, 309-314. http://dx.doi.org/10.1016/j.jbusres.2007.06.017

[37] Eastin, M.J. (2002) Diffusion of E-Commerce: An Analysis of the Adoption of four E-Commerce Activities. Telematics and Informatics, 19, 251-267. http://dx.doi.org/10.1016/S0736-5853(01)00005-3

[38] Oliver, R.L. (1993) Cognitive, Affective and Attribute Bases of the Satisfaction Response. Journal of Consumer Research, 20, 418-430. http://dx.doi.org/10.1086/209358

[39] Hsu. H. (2006) An Empirical Study of Web Site Quality, Customer Value, and Customer Satisfaction Based on E-Shop. The Business Review, 5, 190-193.

[40] Arnold, M.J. and Reynolds, K.E. (2003) Hedonic Shopping Motivations. Journal of Retailing, 79, 259-268. http://dx.doi.org/10.1016/S0022-4359(03)00007-1

[41] Maxwell, S. and Maxwell, N. (2001) Channel Reference Prices: The Potentially Damaging Effects of Napster. Proceedings of the 2001 Fordham University Behavioral Pricing Conference, 32. 
[42] Zeithaml, V. (1988) Consumer Perceptions of Price, Quality, and Value: A Means-End Model and Synthesis of Evidence. Journal of Marketing, 52, 2-22. http://dx.doi.org/10.2307/1251446

[43] Anderson, E.W. and Sullivan, M.W. (1993) The Antecedents and Consequences of Customer Satisfaction for Firms. Marketing Science, 12, 125-143. http://dx.doi.org/10.1287/mksc.12.2.125

[44] Cronin Jr., J.J., Brady, M.K. and Hult, G.T.M. (2000) Assessing the Effects of Quality, Value, and Customer Satisfaction on Consumer Behavioral Intentions in Service Environments. Journal of Retailing, 76, 193-218. http://dx.doi.org/10.1016/S0022-4359(00)00028-2

[45] Biswas, A. and Blair, A.E. (1991) Contextual Effects of Reference Price in Retail Advertisements. Journal of Marketing, 55, 1-12. http://dx.doi.org/10.2307/1252143

[46] Hofacker, C.F. (2001) Internet Marketing. 3rd Edition, John Wiley and Sons, Inc., New York.

[47] Yu, J., Ha, I., Choi, M. and Rho, J. (2005) Extending the TAM for E-Commerce. Information and Management, 42, 965-976. http://dx.doi.org/10.1016/j.im.2004.11.001

[48] Seiders, K., Voss, G.B., Godfrey, A.L. and Grewal, D. (2007) SERVCON: Development and Validation of a Multidimensional Service Convenience Scale. Journal of the Academy of Marketing Science, 35, 144-156. http://dx.doi.org/10.1007/s11747-006-0001-5

[49] Chau, P., Au, G. and Tam, K.Y. (2000) Impact of Information Presentation Modes on Online Shopping: An Empirical Evaluation of a Broadband Interactive Shopping Service. Journal of Organizational Computing and Electronic Commerce, 10, 1-22.

[50] Chen, C.C. and Tseng, Y.D. (2011) Quality Evaluation of Product Reviews Using an Information Quality Framework. Decision Support Systems, 50, 755-768. http://dx.doi.org/10.1016/j.dss.2010.08.023

[51] Bennett, R., Hartel, C.E.J. and Mccoll-Kennedy, J.R. (2005) Experience as a Moderator of Involvement and Satisfaction on Brand Loyalty in a Business-to-Business Setting. Industrial Marketing Management, 34, 97-107. http://dx.doi.org/10.1016/j.indmarman.2004.08.003

[52] Shim, S., Eastlick, M.A. and Lotz, S.L. (2000) Assessing the Impact of Internet Shopping on Store Shopping among Mall Shoppers and Internet Users. Journal of Shopping Center Research, 7, 27-43.

[53] Heiman, A., McWilliams, B. and Zilberman, D. (2001) Demonstrations and Money-Back Guarantees: Market Mechanisms to Reduce Uncertainty. Journal of Business Res, 54, 71-84. http://dx.doi.org/10.1016/S0148-2963(00)00181-8

[54] Rogers, D.S. and Tibben-Lembke, R.S. (1999) Going Backwards: Reverse Logistics Trends and Practices. Reverse Logistics Executive Council, Reno.

[55] Foscht, T. and Ernstreiter, K. (2013) Retaining or Returning (Some Insights for a Better Understanding of Return Behavior). International Journal of Retail and Distribution Management, 4, 113-134. http://dx.doi.org/10.1108/09590551311304310

[56] Forsythe, S.M. and Shi, B. (2003) Consumer Patronage and Risk Perceptions in Internet Shopping. Journal of Business Research, 56, 867-875. http://dx.doi.org/10.1016/S0148-2963(01)00273-9

[57] Bauer, R.A. (1960) Consumer Behavior as Risk-Taking, Dynamic Marketing for Changing World. American Marketing Association, Chicago, 389.

[58] Hsu, M.H. and Chiu, C.M. (2004) Predicting Electronic Service Continuance with a Decomposed Theory of Planned Behavior. Behavior and Information Technology, 23, 359-373. http://dx.doi.org/10.1080/01449290410001669969

[59] Zhao, H. and Li, Y. (2012) International Conference on Applied Physics and Industrial Engineering. Physics, 24, 13041310 .

[60] Jacoby, J. and Kaplan, L. (1972) The Components of Perceived Risk. Advances in Consumer Research, $12,287$.

[61] Peter, J.P. and Tarpey, L.X. (1975) A Comparative Analysis of Three Consumer Decision Strategies. Journal of Consumer Research, 2, 215-224. http://dx.doi.org/10.1086/208613

[62] Brooker, G. (1984) An Assessment of an Expanded Measure of Perceived Risk. Association for Consumer Resources, 11, 439-441.

[63] Schiffman, L.G. and Kanuk, L.L. (1994) Consumer behavior. Prentice-Hall, Englewood Cliffs.

[64] Horton, R.L. (1976) The Structure of Perceived Risk: Some Further Progress. Journal of Academy of Marketing Science, 4, 694-709. http://dx.doi.org/10.1007/BF02729830

[65] Snoj, B., Korda, A.P. and Mumel, D. (2004) The Relationships among Perceived Quality, Perceived Risk and Perceived Product Value. Journal of Product and Brand Management, 13, 156-167. http://dx.doi.org/10.1108/10610420410538050

[66] Walter, Z., Gupta, A. and Su, B. (2006) The Sources of On-Line Price Dispersion across Product Types: An Integrative 
View of On-Line Search Costs and Price Premiums. International Journal of Electronic Commerce, 11, 37-62. http://dx.doi.org/10.2753/JEC1086-4415110102

[67] Xiao, B. and Benbasat, I. (2007) E-Commerce Product Recommendation Agents: Use, Characteristics and Impact. MIS Quarterly, 31, 137-209.

[68] Morgan-Thomas, A. and Veloutsou, C. (2013) Beyond Technology Acceptance: Brand Relationships and Online Brand Experience. Journal of Business Resources, 66, 21-27. http://dx.doi.org/10.1016/j.jbusres.2011.07.019

[69] Jacoby, J. and Kaplan, L.B. (1972) The Components of Perceived Risk. Proceedings of the Annual Conference of the Association for Consumer Research, 10, 382-393.

[70] Guda, V.N., Kerkhof, P. and Fennis, B.M. (2008) The Persuasiveness of Online Safety Cues: The Impact of Prevention Focus Compatibility of Web Content on Consumers' Risk Perceptions, Attitudes and Intentions. Journal of Interactive Marketing, 22, 58-72. http://dx.doi.org/10.1002/dir.20121

[71] Ryan, G. and Valverde, M. (2005) Waiting for Service on the Internet: Defining the Phenomenon and Identifying the Situations. Internet Research, 15, 220-240. http://dx.doi.org/10.1108/10662240510590379

[72] Chang, D.S. and Wang, T.H. (2012) Consumer Preferences for Service Recovery Options after Delivery Delay with Shopping Online. Social Behavior and Personality: An International Journal, 40, 1033-1044. http://dx.doi.org/10.2224/sbp.2012.40.6.1033

[73] Chang, M.K., Cheung, W.M. and Lai, V.S. (2005) Literature Derived Reference Models for the Adoption of Online Shopping. Information and Management, 42, 543-559. http://dx.doi.org/10.1016/j.im.2004.02.006

[74] Anderson, R.E. and Srinivasan, S.S. (2003) E-Satisfaction and E-Loyalty: A Contingency Framework. Psychology and Marketing, 20, 123-138. http://dx.doi.org/10.1002/mar.10063

[75] Oliver, R.L. (1997) Satisfaction: A Behavioral Perspective on the Consumer. The McGraw-Hill Companies, Inc., New York.

[76] CNNIC (2012) China Internet Network Information Center. The 30th Statistical Report on Internet Development in China. http://www.cnnic.com.cn/

[77] Parasuraman, A., Zeithaml, V.A. and Berry, L.L. (1988) SERVQUAL: A Multiple Item Scale for Measuring Consumer Perceptions of Service Quality. Journal of Retailing, 64, 12-40.

[78] Fornell, C. and Larcker, D. (1981) Evaluating Structural Equation Models with Unobservable Variables and Measurement Error. Journal of Marketing Research, 18, 39-50. http://dx.doi.org/10.2307/3151312

[79] Bagozzi, R.P. and Yi, Y. (1988) On the Evaluation of Structural Equation Models. Journal of the Academy of Marketing Science, 16, 74-94. http://dx.doi.org/10.1007/BF02723327

[80] Garson, D.G. (2008) Factor Analysis: Statnotes. Retrieved 15 October 2014, from NorthCarolina State University Public Administration Program. http://www2.chass.ncsu.edu/garson/pa765/factor.htm

[81] Dillon, T. and Reif, H.L. (2004) Factors Influencing Consumers Factors Influencing Consumers: E-Commerce Commodity Purchases Commerce Commodity Purchases. Information Technology, Learning, and Performance Journal, 22, 230-233. 